\title{
How Linguistic Notions Formed the Concession During the Grammaticalization Process? A Contrastive Study of the Mandarin Concessive Connector 即使 jísh ̌̌ and Its Equivalents in French
}

\author{
Ming HUANG \\ Ph.D. Candidate \\ Department of French Language \\ Université Paris-Sorbonne (Paris IV) \\ France
}

\begin{abstract}
The article treats the most prototypical concessive connector 即使 jishř "although" "even if" in Chinese and its equivalents in French based on previous theories and analyses on the two languages. The aim of the present work is to explore the concessive mechanism in two languages that are typologically distant. By relating several crucial linguistic notions such as temporality, hypothesis and causative verbs, our research not only demonstrates the diachronic evolution of the concessive marker 即使 jishǐ, but also highlights its rapprochements with certain French concessive connectors (such as cependant, mêmesi, etc.) from logico-semantic and syntactico-discursive points of view. After consulting various corpora from archaic to contemporary Chinese and French, as well as using technical linguistic methodologies, the article presents surprising similarities in terms of the concessive formation despite the etymological and cultural differences of the two languages.
\end{abstract}

Keywords: Concessive connectors, Mandarin, French, hypothesis, temporality, causality

\section{Introduction}

\subsection{Notion of concession in French and in Mandarin}

The idea of concession dates to the rhetoric field and becomes more and more precise from medieval and classical eras in French (Soutet, 1990, p. 3-5). It was not until the course of the $19^{\text {th }}$ century that the term concession enters the grammatical lexicon and was defined by the grammarians as a logical relation uniting two propositions. It is not a coincidence that the ancient rhetoricians and grammarians have always listed and studied this rhetorical figure. The concession, which has extremely rich, varied and nuanced means of expression, plays a specific and irreplaceable role in our discourse. It is defined as a two-step argument movement (Morel, 1996, 5): "The speaker begins by recognizing the validity of an argument that he lends to his opponent in the debate. Then he enunciates a counter-argument that comes to restrict the scope or destroy it."

Mandarin Chinese is an isolating language with a reduced morphology belonging to the Sino-Tibetan languages. Since the dawn of the first systematic work on the Mandarin Chinese's grammar Ma Shi Wen Tong (The grammar of Ma) in 1898, the conjunction, as one of the most important functional categories (also named "empty categories" by the author), was first introduced in an independent chapter. This establishes the importance of its role in the grammatical scope. One of its sub-classifications, concessive conjunctions, is the most problematic category. According to Chinese linguists, the concessive sentence belongs to the complex sentence field whose subordinate has a position opposite to that of the principal. In a concessive phrase, the enunciator provisionally "allows" or "admits" the assertion or hypothesis of the subordinate by using it as a concession in the discourse (J. Li, 1924). In fact, the said "concession" is thus a temporary admission (S. Lü, 1956). This is the reason why some Chinese linguists also called concessive conjunctions "permissive" conjunctions.

However, the concessive link is not restricted to a simple logical relation but is a complex operation. On a logicocausal level, the concession is a cause that should have acted but did not act. The concessive mechanism combines many already complex linguistic notions that are often studied separately by linguists: temporality, intensity, negation, causality, subjectivity, etc. All together, they constitute the concessive operation. 
Therefore, it is often said that the concession is a "secondary" or "composed" linguistic concept, and it is almost impossible to find a simple or archaic word expressing the concession in many languages.

\subsection{Theoretical research on concession in France and in China}

In France, thematic work on concessive connectors was mainly conducted in the 1980s and 1990s, represented by two important theses of M.-A. Morel and O. Soutet, published respectively in 1980 and 1990. These two authors, from lexico-syntactic and diachronic-semantic points of view, study the definitions and explanations of concession given by grammarians up to the $20^{\text {th }}$ century, as well as the origins of concessive expressions in the $16^{\text {th }}$ century and their grammaticalization process during history. R. Martin (1987) devoted a chapter to the study of the worlds involved in a concessive relation from the angle of formal semantics. He proposes the "underlying implication" (R. Martin, 1987), a logical mechanism of primacy in the concessive relation: something is expected to arise from an existing situation. H. Gettrup and H. Nølke (1984) are particularly interested in concessive adverbial morphemes in French. Also inspired by "the Geneva School”, P. Blumenthal (1980) and O. Ducrot (1984) deal with several relevant linguistic notions such as adversity and the act of speech in their work. J.C. Anscombre $(1985,2001)$ explains in his articles the relations between the concession and the causality, the negation, the condition from logical and argumentative points of view. S. Mellet (2008) dedicates a work that deals, over a wide range of corpora, with concessive connectors in French through the centuries from syntactic and argumentative angles.

In China, researchers have considerably been deepening the properties, constraints, and subdivisions of concessive conjunctions since the embryonic stage of the modern Chinese grammar system. J. Li (1924), one of the founders of Chinese grammar, distinguishes two types of concessional conjunctions. For the first one, represented by 虽然 suīrán “despite", and its various derivatives (such as 虽是 suīshi and 虽说 suīshūo, whose first morpheme means "despite" and the second morphemes mean respectively "to be" and "to say"), it is a question of introducing an assertion from a certain fact. For the second, represented by 即使 jish 然 zòngrán and its derivatives, as well as 哪怕 năpà, they all mean "although" or “even if” according to the linguistic context. In contrast to "allowing" a certain assertion, this second type of concessive conjunctions is often used as a basis for psychological "presupposition". L. Wang (1944), who has a very similar point of view, considers that 虽然 suĩrán "despite" and its derivatives belong to the concessive conjunctions of "real permission", while the other expressions mentioned above are concessive markers of "hypothetical permission". According to S. Lü (1956), the clause introduced by 虽然 suĩrán “despite", as well as that introduced by 即使 jísh "although" or "even if", are all concessive clauses. For the author, there is a logic in relation to the concessive subordinate: in a sentence in the form of "[Concessive connector] $+q, p$ " either "the cause of $q$ does not produce the consequence of $p$ " or "the consequence of $p$ nevertheless occurs despite the defect of the cause of $q$ ". He listed for the first time another kind of concessive proposition in the form of a concessive conjunction: 就 是 jiùshi "although" or "even if" whose first morpheme means "immediately", and the second means "to be", directly followed by a noun instead of a subordinate with the complete SVO. Since the year 2000, the work on the subject concerns in principle two branches: the uses of concessive conjunctions in the complex sentence from the logico-syntactic point of view, and the grammaticalization of the concessive markers. Important research on the two approaches above include the book by H. Li (2013) on the concession and the relevant issues, and the research by C. Chi and Y. Ling (2008), Z. Li (2017), and K. Wu (2006) on the grammaticalization of certain concessive markers.

Based on previous research and combining theoretical currents on both sides in French and Chinese, we will try to analyze the most typical and frequently used concessive marker in contemporary Chinese: 即使 jísh ̌ “although" "even if" "if". We will also try, from a logico-semantic and syntactico-discursive point of view, to highlight their links with French, an Indo-European inflectional language, during the process of grammaticalization of these concessive conjunctions. We will surprisingly notice how these two languages "thicken" their concessive mechanism in a very similar way through the grammaticalization process despite their enormous linguistic and cultural divergences.

\section{Concessive marker 即使 jísh ̌ “although" "even if” and its brief grammaticalization history}


即使 jíshř “although" “even if”, which can be interpreted as the hypothesis connector "if" in some cases as well, is one of the most typical concessive conjunctions in contemporary Chinese. It is often at the top of the clause, followed by a postponed main clause that semantically opposes the logic of the previous one.

Like most concessive markers, 即使 jísh i is a "composed" or "secondary" connector, and was a syntactic construction combining two morphemes 即 $j i ́$ and 使 shǐ in history. 即 $j i$ is a polyseme that can act as five different parts of speech: noun, verb, adverb, preposition and conjunction. When it plays the conjunction role, it has either the concessive meaning "although" "even if" (example 1) or the hypothetical meaning "if" (example 2). When used as an adverb, it indicates the temporality of two events that happen very quickly or nearly simultaneously, "at the same time" so to speak (example 3). For instance:

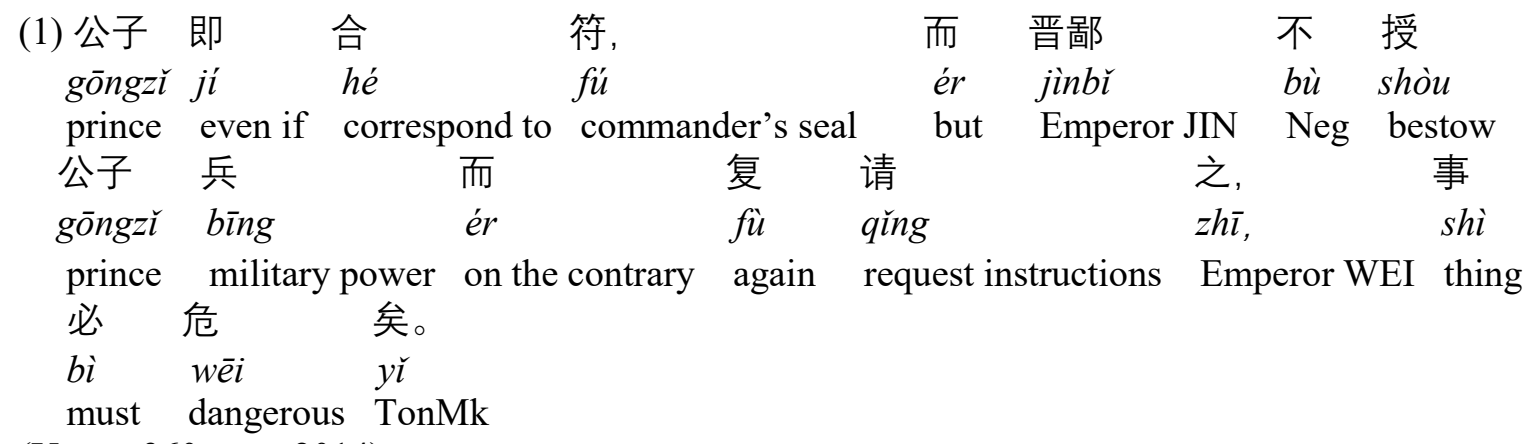

(Yuwen360.com, 2014)

"Even if the prince showed his royal seal and the tally was verified, Emperor Jin might still not hand over the regime to the prince but request again directions from Emperor Wei (the enemy of the prince), then the situation is going to be dangerous."

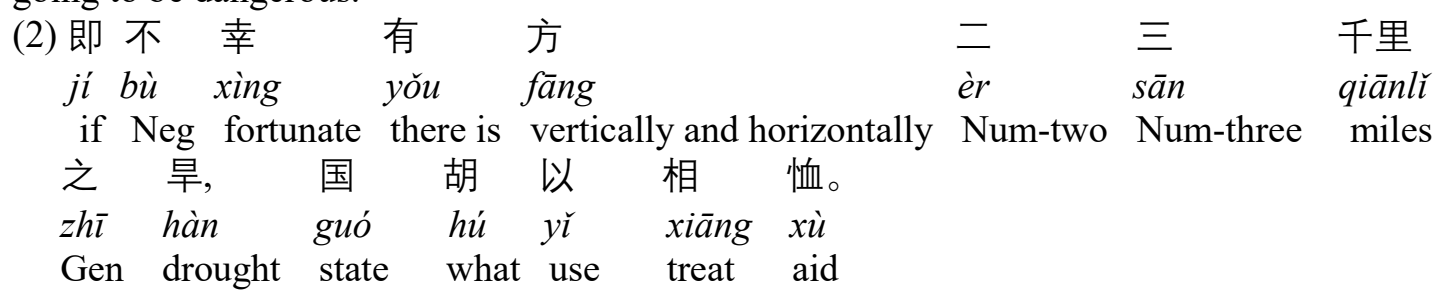

(Fanti.dugushici.com, 2015)

"If the unfortunate drought has occurred over two or three thousand miles (scale), what should the state use to relieve (the people)?”

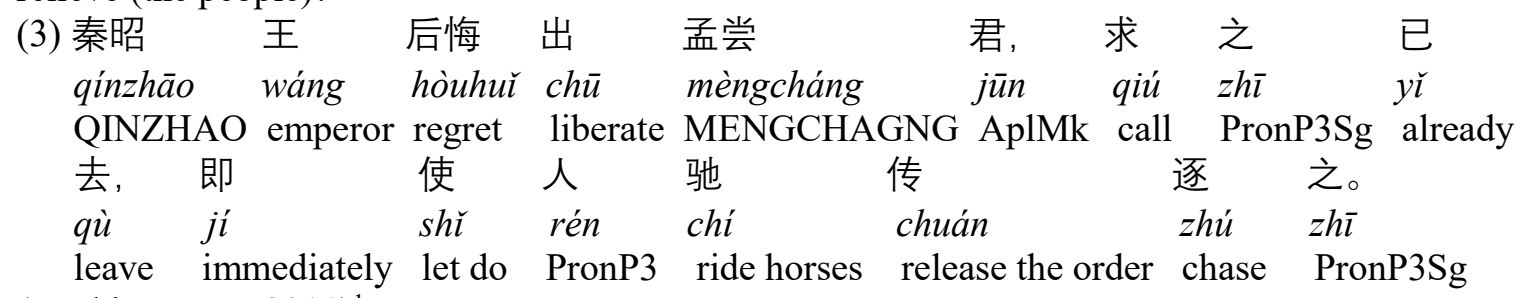

(Gushiwen.org, 2011) $)^{1}$

"Emperor Qinzhao regrets to release Mengchang. He's willing to call him, but Mengchang has already left. Emperor Qinzhao immediately gave the order to his men to mount their horses and chase him."

使 shř is also a polyseme, which can act as noun, verb and conjunction. It is mainly used as a causative verb, meaning "to let (someone) do something" "to make something happen", but also used as a hypothetical conjunction "if" in archaic corpus:

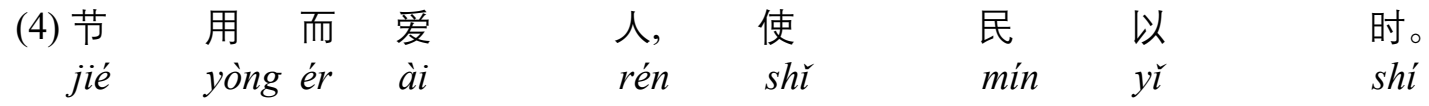
save use and take care of people getworking people according to agricultural seasons (Guoxue.com, 2000)

"Saving financial expenses and taking care of the people, get people working but not delay the time of farming."

${ }^{1}$ Cited by Chi, C., \& Ling, Y. (2008): Rangbuliancijishi de yufahua. Jiangnan daxuexuebao, 7(2), p. 92. 


\begin{tabular}{|c|c|c|c|c|c|c|c|c|}
\hline (5) 向 & 使 & $\equiv$ & 国 & 各 & 爱 & 其 & 地, & 齐 \\
\hline xiàng & $s h \grave{i}$ & $s \bar{a} n$ & guó & $g \grave{~}$ & $\grave{a} i$ & $q i$ & $d i$ & $q i$ \\
\hline & if & Num-three & states & respectively & love & Gen & national territory & State QI \\
\hline 人 & 勿 & 附 & 于 & 秦。 & & & & \\
\hline rén & $w \grave{u}$ & $f \grave{u}$ & $y u^{\prime}$ & qin & & & & \\
\hline
\end{tabular}

people Neg depend on toward State QIN

(Gushiwen.org, 2011)

"If the people of the three states love their own territories, the people of State Qi do not depend on State Qin."

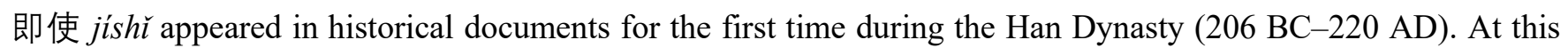
time, 即使 jish “immediately" + the causative verb 使 shǐ "to let (someone) do (something)" "to get/have (something) done" (C. Chi and Y. Ling 2008, 92). For example:

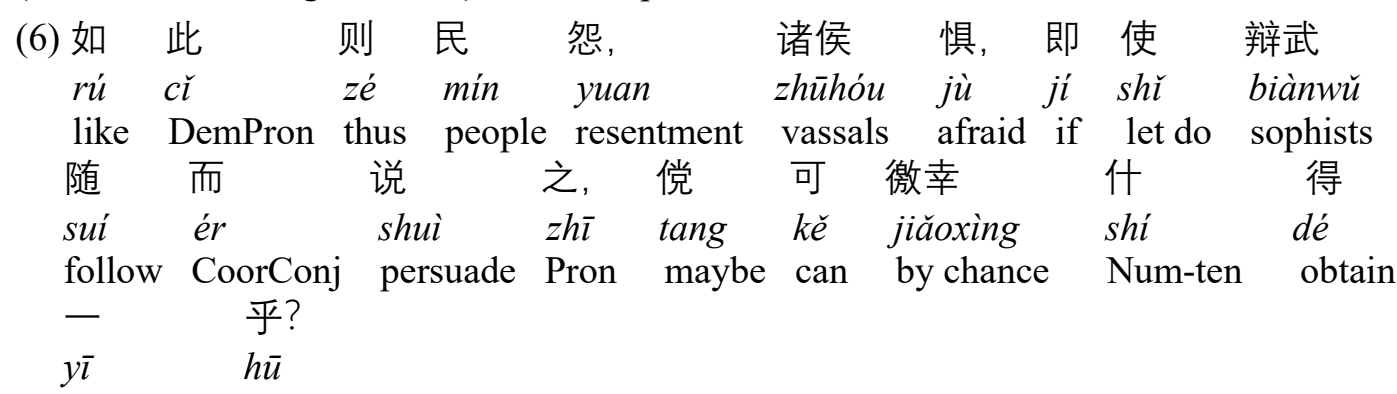

Num-one TonPtcl

(Guoxue.com, 2000) $)^{2}$

"If you (the emperor) do this, people will be resentful, and vassals will be afraid. If you order sophists to persuade the people and the vassals, you may have one chance out of ten to win their support."

During the Six Dynasties (220 AD-589 AD), the syntactic construction 即使 jish combination of the hypothetical conjunction 即 $j i$ "if" + the causative verb 使 shĭ "to let (someone) do (something)" "to get/have (something) done". For instance:

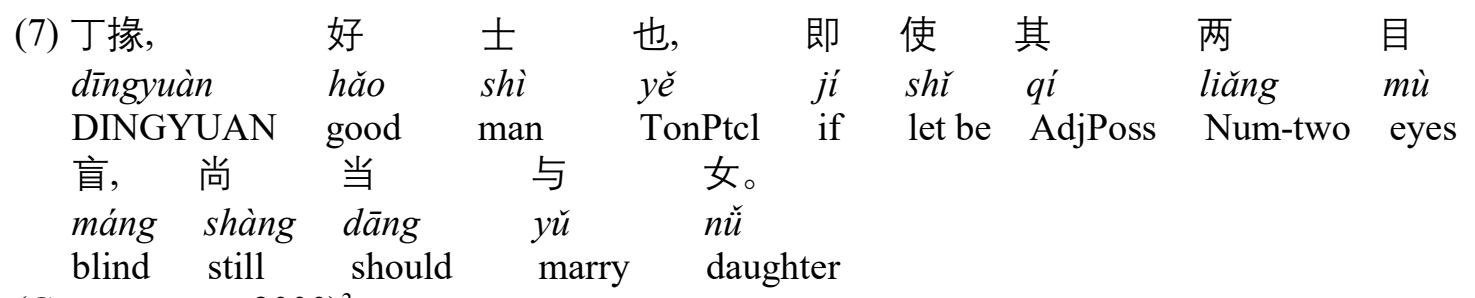

(Guoxue.com., 2000) ${ }^{3}$

"Dingyuan is such a nice person. If he goes blind, he is still worth marring my daughter."

We share the same opinion with C. Chi and Y. Ling $(2008,93)$ here: if we compare example (7) with example (6), we will observe that what follows 使 shı in example (6) is a concrete action: allowing/ordering eloquent persons to persuade people and vassals. However, "becoming blind" in example (7) is a hypothetical state. Since this period of the Six Dynasties (220 AD-589 AD), 使 sh $\iota$ has been expressing "to make someone be in a state" instead of "to have an action done by someone". Its semantic meaning becomes more and more abstract and

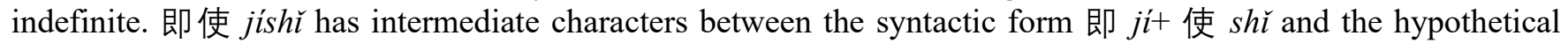
conjunction 即使 jíshǐ.

It is approved by the linguists that the syntactic construction "temporal adverb/hypothetical conjunction 即 $j i$ ' the causative verb 使 shi” began to grammaticalize towards a concessive conjunction during the Ming dynasty (13681644). For example:

${ }^{2}$ Cited by Chi, C., \& Ling, Y. (2008).Ibid.

${ }^{3}$ Cited by Chi, C., \& Ling, Y. (2008).Ibid., p. 93. 


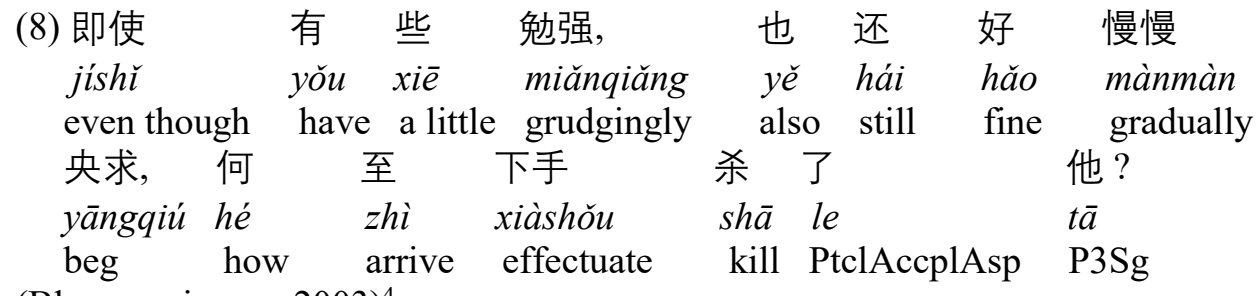

(Blogapp.sina.cn, 2003) ${ }^{4}$

"Even though (she) did this a little stubbornly, I could always beg her to do so. How come that I killed her?"

We can observe from this example that 使 shr plays no longer the role of causative verb: its meaning of "to let (someone) do (something)" disappears. Moreover, semantically, the subjectivity of 即使 jísh did this a little stubbornly" is no longer an objective result of "to do" but a subjective feeling of the enunciator. In modern Chinese, 即使 jish ȟ having finished its grammaticalization process has become a concessive conjunction.

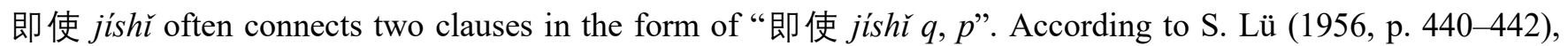
clause $q$ actualizes the concessive hypothesis. On the other hand, F. Xing thinks that the proposition q introduced

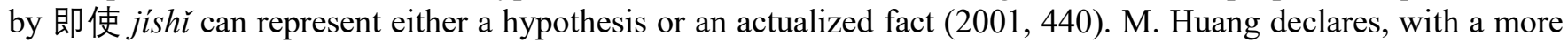
modest opinion, that 即使 jishǐ has two values: "a value of logical concession: the fact introduced in the concession is given as discounted, and a value of concession and hypothesis: the fact introduced in the concession is given as fictitious." $(2005,192)$. Therefore, depending on the context, the concessive connector 即使 jísh $\iota \check{c}$ can be translated either by "although" often introducing an actualized fact, or by "even if" introducing a hypothesis. No grammatical element decides the interpretation will go towards "although" or "even if". For instance:
(9) 即使
他 很
很富有，他 也
jíshǐ
tā hěn füyǒu tā yĕ
买不到幸福
măi bùdào xìngfú
even though/even if
$\mathrm{P} 3 \mathrm{Sg}$ very rich
$\mathrm{P} 3 \mathrm{Sg}$
与 健康。
yŭ jiànkāng
and health

"He cannot buy happiness and health although he is/even if he is rich."

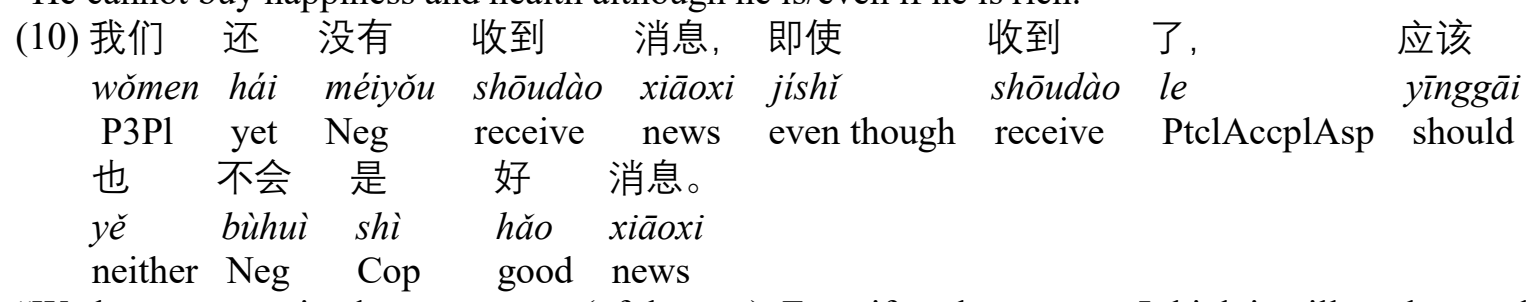

"We have not received any news yet (of the war). Even if we have some, I think it will not be good news."

\section{Concession: a combination of temporality, causality and hypothesis}

\subsection{Concession and temporality}

Just as mentioned above, 即 $j i$ is a polyseme, which is not only a hypothetical (concessive) conjunction, but also an adverb of time, which means "immediately". In comparison to French, we can observe here how the language uses temporal construction to serve the concession. This phenomenon is found in the French adverb cependant, which means etymologically pendant ce temps "during this time" "during that". The demonstrative adjective insists on the temporal simultaneity of two situations. There is still in contemporary French a slightly literary conjunctive phrase cependant que, which is purely temporal (example 11). For example:

(11) Cependant que j' attendais l' autobus, $j^{\prime}$ ai lu mon journal. during the time P1Sg wait for the bus P1Sg Aux read Gen newspaper

"While waiting for the bus, I read my newspaper."

The phrase cependant que does not become concessive in contemporary French. Yet, on the other hand, the adverb cependant on the other hand has no longer the temporal value. It became an adversarial circumstantial 
morpheme then slipped into the concession. Thus, we can observe an interesting discordance between the adverb of time and the conjunctive phrase here. According to the studies of S. Mellet $(2008,203)$, the anaphoric morpheme ce ("this") "favors the emergence of a logical relation", and cependant found its use of opposition in the $16^{\text {th }}$ century for the first time. Itis a main adverb in French presenting the contrast and the concession. It is thus interpreted by "however" "nevertheless" (example 12) or "all the same" "though" (example 13):

(12) Les deux chats sont frères. Cependant, ils ont des caractères très différents. the Num-two cats Cop brothers however P3P1 Aux some characters very different

"The two cats are brothers. However, they have very different characters."

(13) Le restaurant $n$ ' est pas cher. Le dîner, cependant, est délicieux. the restaurant Neg Cop Neg expensive the dinner though Cop delicious

"The restaurant is not expensive. The dinner, though, is delicious."

Furthermore, we can also find how the temporal 即 $j i$ "immediately" is easily combined with the hypothetical causality marker 使 shì "to let (someone) do (something)" during the grammaticalization process. In French, this analogous phenomenon is represented by alors, which is originally a temporal adverb meaning "then", and that is gradually used as the consequence conjunction "so". For instance, in the following example, we employ the temporal adverb alors to indicate the relation cause-consequence instead of a hypothetical complex sentence:

$\begin{array}{clllll}\text { (14) Il pleut, alors je prends mon parapluie. } & \text { men } \\ \text { P3Sg raining so P1Sg take } & \text { Gen umbrella }\end{array}$

"It's raining, so I take my umbrella."

(15) $S^{\prime}$ il va pleuvoir, je prendrai mon parapluie.

if P3Sg Aux rain P1Sg take Gen umbrella

"If it's going to rain, I'll take my umbrella."

\subsection{Concession and causality}

Through the concessive connector 即使 jish ȟ , we observe that the concession is often associated with the causality idea "to let (someone) do (something)". According to O. Soutet (1990) and M.-A. Morel (1983), the concession is at first a rhetorical figure. This leads us to think, from a rhetorical point of view, that the speaker abandons an argument to his opponent by "letting" his opponent express himself. We often see the concessive structure in French certes, j'accepte..., mais... "admittedly, I accept..., but....". It is in fact a mechanism of admitting temporarily but to reverse afterward. It could be the reason why causative verbs like 使 shi are at the heart of the grammaticalization process of concessive connectors.

There is an obvious causal connection in the concession: the concession is a form of causality, which is normally verified but is not verified. When we say the following sentence:

(16) Bienqu' il fasse beau, j' ai pris mon impermeable. even though $\mathrm{P} 3 \mathrm{Sg}$ do nice $\mathrm{P} 1 \mathrm{Sg}$ aux take Gen raincoat

"Although the weather was nice, I took my raincoat."

There is a link between the "good weather" and the fact of "having a raincoat". The expected causality order does not work: what is expected is when the weather is nice people normally do not need to take a raincoat. There is thus an established link between the weather and the type of clothing I wear. Here, the actualized hypothesis (qu'il fasse beau "the weather was nice") and the concession (j'ai pris mon imperméable "I took my raincoat") establish together the "abnormal" causality mechanism: with the actualized hypothesis, we are in the possible causeconsequence order that could have been effective; with the concession, we are in the situation where the cause is denied by the fact.

\subsection{Concession and hypothesis}

As mentioned in previous paragraphs, 即使 jishǐ represents a concession value "although" "even if" or a hypothesis one "if" in contemporary Chinese. When used as a concessive conjunction, the fact introduced by 即

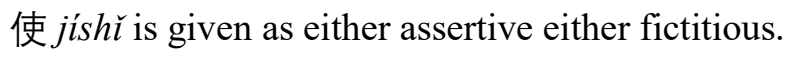

In contemporary French, the hypothetical concessive marker is primarily represented by même si "even if" followed by the indicative mode. However, $s i$ "if" is not always hypothetical in French. It also has a contrastive value introducing an actualized fact. For example: 
$\begin{array}{rllllll}\text { (17) } \mathrm{Si} & \text { Peter } & \text { est } & \text { courageux, Paul, } & \text { lui, } & \text { est } & \text { singulièrement paresseux. } \\ \text { so } & \text { PETER } & \text { Cop } & \text { brave PAUL } & \text { P3Sg } & \text { Cop particularly lazy }\end{array}$

"Peter is so brave. As for Paul, he is particularly lazy."

This statement insists on the contrast between the braveness of Peter and the laziness of Paul. The link here is not from cause to consequence, but a contrastive one. This usage of si has an influence on the interpretation of même $s i$ "even if": besides the concessive connector même si integrating a hypothetical si, there is another one integrating a contrastive si introducing an actualized fact that is almost equivalent to bien que "although" "even though". For example:

(18) Mêmesi j' étais riche,je n' achèterais pas une Ferrari. even if P1Sg Cop rich P1Sg Neg buy Neg a FERRARI

"Even if I were rich, I would not buy a Ferrari."

(19) Mêmes' il est malade, il vient au cours. although P3Sg Cop sick P3Sg comes to the class

"Although he is sick, he comes to class."

Example (18) is typically a hypothetical concessive: the hypothesis presents a cause-consequence link: if I were rich, I would buy a Ferrari. On the other hand, the example (19) can be interpreted differently: even if it is true that he is sick, he nevertheless comes to the class. This is a si "if" we can interpret as "if it is true that". Here, we leave the field of hypothesis to enter the factuality. More examples can be found in historical accounts in which même si "even though" is applied to introduce existing events. For example:

(20) En 1918, même si la France a gagnéla guerre, elle n' en est in 1918 although the France Aux win the war P3Sg Neg Pron Cop

pas moins affaiblie.

Neg minus weakened

"In 1918, even though it won the war, France was nonetheless weakened."

No one disputes the statement above because it is an historical fact thus an assertion.

\section{Conclusion}

In this present paper, we presented our contrastive analyses of the most prototypical concessive marker in contemporary Chinese 即使 jíshǐ “although" “even if” as well as its equivalents in French. From logico-semantic and syntactico-discursive points of view, we have not only presented briefly how the concessive marker 即使 jísh was formed in a diachronic way, but also highlighted its similarities with French as far as the grammaticalization process is concerned. 即使 jísh was initially a syntactic construction of two morphemes of different natures: the temporal adverb/hypothetical (concessive) conjunction 即 $j i+$ the causative verb/hypothetical conjunction 使 shř. The study of 即使 jish $h \grave{l}$ leads us to analyze how the grammar, no matter the studied languages typologically distant, uses temporality, causality and hypothesis in the composition of concession. To conclude, the concession is a complex logical relationship nourished by an aggregation of simple signs. That may be the reason why, even though many researchers studied the concession in recent years in both Chinese and French, it is constantly attracting the attention of new researchers willing to continue deepening this subject. 


\section{Abbreviation Table}

\section{References}

\begin{tabular}{|l|l|}
\hline Abbreviation Table & Adjective possessive \\
\hline AdjPoss & Appellation Mark \\
\hline AplMk & Auxiliary \\
\hline Aux & Copula \\
\hline Cop & Conjunction of coordination \\
\hline CoorConj & Demonstrative \\
\hline Dem & Genitive \\
\hline Gen & Negation \\
\hline Neg & Number \\
\hline Num & First Person \\
\hline P1 & Third person \\
\hline P3 & Plural \\
\hline P1 & Pronoun \\
\hline Pron & Particle of accomplished aspect \\
\hline PtclAccplAsp & Singular \\
\hline Sg & Tonic Particle \\
\hline TonPtcl & \\
\hline
\end{tabular}

Anscombre, J. C. (1985). Grammaire traditionnelle et grammaire argumentative de la concession. Revue Internationale de Philosophie, 55, 333-349.

Anscombre, J. C. (2001). Le rôle du lexique dans la théorie des stéréotypes. Langages, 142, 57-76.

Blogapp.sina.cn. (2003). Erkepai'anjingqi Juanershiba. [online] Available at: https://goo.gl/aBQhqa [Accessed 19 Aug. 2018].

Blumenthal, P. (1980). La syntaxe du message. Application au français moderne. Tübingen: Max Niemyer Verlag. Chao, Y. (1985). A Grammar of Spoken Chinese. Berkeley and Los Angeles: University of California Press.

Chi, C., \& Ling, Y. (2008): Rangbu lianci jishi de yufahua. Jiangnan daxue xuebao, 7(2), 91-96.

Chomsky, N. (1957). Syntactic Structures. The Hague: Mouton \& Co.

Ducrot, O. (1984). Le dire et le dit. Paris: Les Éditions de Minuit.

Fanti.dugushici.com. (2015). Lun jizhu shu. [online] Available at: https:/goo.gl/oNu1Z1 [Accessed 14 Aug. 2018].

Gettrup, H., \& Nølke, H. (1984). Stratégies concessives: Une étude de six adverbes français. Revue Romane, 19(1), 3-47.

Givón, T. (1994). Irrealis and the subjunctive. Studies in Languages, 18(2), 265-337.

Gushiwen.org. (2011). Shiji Qishiliezhuan Mengchangjunliezhuan. [online] Available at: https://goo.gl/frtCVZ [Accessed 14 Aug. 2018].

Gushiwen.org. (2011). Liuguolun Wenshuo. [online] Available at: https://goo.gl/9r33R7 [Accessed 17 Aug. 2018 ].

Guoxue.com. (2000). Lunyu Xueer. [online] Available at: https://goo.gl/CySfVx [Accessed 14 Aug. 2018].

Guoxue.com. (2000). Shiji Huainanhengshanliezhuan Diwushiba. [online] Available at: https://goo.gl/S5e12q [Accessed 17 Aug. 2018].

Guoxue.com. (2000). Sanguozhi Wishu Shijiu. [online] Available at: https://goo.gl/3hgv4r [Accessed 18 Aug. 2018].

Huang, M. (2005). Les Expressions Temporelles et logiques en français et en chinois: Étude Contrastive et Exploitation Pédagogique. Taipei: Zhongyang Guoshu Publishing House.

Li, C. N., \& Thompson, A. S. (1981). Mandarin Chinese: A Functional Reference Grammar. Berkeley: University of California Press.

Li, H. (2013). Xiandai hanyu rangbu fanchou ji xiangguan wenti de renzhi yanjiu. Beijing: Zhongguo Shehui Kexue Publishing House.

Li, J. (1924). Xinzhu guoyu wenfa. Beijing: Commercial Press.

Li, Z. (2017). Yufahua yu hanyu shici xuhua. Shanghai: Xuelin Publishing House. 
Ling, Y. (2007). Rangbu lianci yanbian ji yufa gongneng yanjiu lishuo. Hangzhou: Zhejiang University.

Lindschouw, J. (2011). Études des modes dans le système concessif en français du $16^{e}$ au $20^{e}$ siècle et en espagnol moderne. København: University of Copenhagen, Museum Tusculanum Press.

Lü, S. (1956). Zhongguo wenfa yaolue. Beijing: Shangwu yingshuaguan.

Ma, J. (1898). Ma Shi Wen Tong. Shanghai: Commercial Press.

Martin, R. (1987). Langage et croyance. Les "univers de croyance" dans la théorie sémantique. Brussels: Pierre Mardaga.

Meillet, A. (1984). L'évolution des formes grammaticales. In A. Meillet, Linguistique historique et linguistique générale (pp. 130-148). Paris: Édouard Champion.

Mellet, S. (2008). Concession et dialogisme : les connecteurs concessifs à l'épreuve des corpus. Bern, Berlin and Brussels: Peter Lang.

Morel, M.-A. (1980). Études sur les moyens grammaticaux et lexicaux propres à exprimer une concession en français contemporain. Paris: Université Sorbonne Nouvelle.

Morel, M.-A. (1996). La concession en français. Paris: Ophrys.

Paris, M.-C. (2003). Linguistique chinoise et linguistique générale. Paris: l'Harmattan.

Soutet, O. (1990). La concession en français des origines au XVIe siècle. Problèmes généraux. Les tours prépositionnels. Geneva: Librairie Droz S. A.

Soutet, O. (1992). La concession dans la phrase complexe en français. Des origines au XVI siècle. Geneva: Libraire Droz S. A.

Wang, L. (1944). Zhongguo yufa lilun. Beijing: Zhonghua shuju.

Wu, K. (2006). Suiran de yufahua tanxi. Jinggangshan xueyuan xuebao (zhexue shehui kexue), 27(11), 67-69.

Xing, F. (2001). Hanyu fuju yanjiu. Beijing: Commercial Press.

$\mathrm{Xu}, \mathrm{T}$. (2009). Lianci jishi de lishi kaocha. Henna keji xueyuan xuebao, 2, 157-160.

Yuwen360.com. (2014). Shiji Weigongziliezhuan. [online] Available at: https://goo.gl/e2E5md [Accessed 30 Aug. 2018].

Zhang, Z. (1956). Hanyu yufa changshi. Beijing: Xin Zhishi Publishing House.

Zhou, G. (2002). Lianci yu xiangguan wenti. Hefei: Anhui Jiaoyu Publishing House.

Zhu, D. (1983). Yufa jiangyi. Beijing: Commercial Press. 